\title{
(息)
}

Citation:

Sterchele, D (2013) Fertile land or mined field? Peace-building and ethnic tensions in post-war Bosnian football. Sport in Society, 16 (8). 973 - $992 . \quad$ ISSN 1743-0437 DOI: https://doi.org/10.1080/17430437.2013.801223

Link to Leeds Beckett Repository record:

https://eprints.leedsbeckett.ac.uk/id/eprint/1804/

Document Version:

Article (Accepted Version)

The aim of the Leeds Beckett Repository is to provide open access to our research, as required by funder policies and permitted by publishers and copyright law.

The Leeds Beckett repository holds a wide range of publications, each of which has been checked for copyright and the relevant embargo period has been applied by the Research Services team.

We operate on a standard take-down policy. If you are the author or publisher of an output and you would like it removed from the repository, please contact us and we will investigate on a case-by-case basis.

Each thesis in the repository has been cleared where necessary by the author for third party copyright. If you would like a thesis to be removed from the repository or believe there is an issue with copyright, please contact us on openaccess@leedsbeckett.ac.uk and we will investigate on a case-by-case basis. 
This is the author's post-print version.

To cite this article: Davide Sterchele (2013) Fertile land or mined field? Peace-building and ethnic tensions in post-war Bosnian football, Sport in Society: Cultures, Commerce, Media, Politics, 16:8, 973-992, DOI: 10.1080/17430437.2013.801223

To link to this article: http://dx.doi.org/10.1080/17430437.2013.801223

\title{
Fertile land or mined field? Peace-building and ethnic tensions in post-war Bosnian football
}

\section{Davide Sterchele}

Department of Philosophy, Sociology, Education and Applied Psychology, University of Padua, Padua, Italy

\begin{abstract}
With the outbreak of the war in Bosnia and Herzegovina (BiH), each ethno-national group - Bosnian Muslims (Bosniaks), Bosnian Serbs and Bosnian Croats - set up its own football federation and began to organize its own competitions separately. Nevertheless, under strong pressure from FIFA, UEFA and the IOC, the three football establishments finally agreed to merge into a unified Bosnian Football Federation in 2002 and to organize the Premijer Liga, the first united Bosnian post-war championship. Drawing on ethnographic studies conducted in BiH since 2003, the paper examines the consequences of such a revamped inter-ethnic competition both in terms of the re-integration of the Bosnian population, on the one hand, and the possible exacerbation of ethnic tensions, on the other. It is concluded that the reunification of the Bosnian football's landscape helps to demonstrate how ethnicity is instrumentally used by the post-war elites to exploit the common good for private enrichment.
\end{abstract}

\section{Introduction}

Oh, if the people had their way, there wouldn't be any problem at all! People are already ready to play all together in mixed championships. We already play friendly matches with Serb or Croat teams, indeed. The problem is only a political one: it is at the top of the political level that they make every effort to maintain the separations.

With these words, a Bosniak coach introduced me into the controversial world of football in Bosnia and Herzegovina (henceforth $\mathrm{BiH}$ ) at the beginning of my fieldwork in 2003, confirming how sport, and notably football, functions as a contentious site for social, cultural and political representations ${ }^{1}$ in the interplay between territory, politics and identity. $^{2}$ Although sport has usually provided some space for the expression of resistance 
in former communist regimes, ${ }^{3}$ the new political apparatuses emerging from the breakdown of the latter seem to have inherited and maintained, especially in the Balkans, the old capacity to ignore the claims coming from the sporting sphere, thereby limiting its allegedly transformative potential.

Towards the end of the 1980s, Yugoslavian football had undergone a progressive politicization. The emerging nationalist elites utilized the sport as a basis for personal enrichment, construction of power at the local level and political self-legitimization in the eyes of their own national groups. With the outbreak of the war in $\mathrm{BiH}$, each ethnonational group - Bosniaks (Bosnian Muslims), Bosnian Croats and Bosnian Serbs - set up its own football federation and began to organize its own competitions separately. After the war, Bosnian football was in a catastrophic condition, divided between three separate mono-ethnic federations, lacking financial and structural resources and controlled by incompetent speculators coming from outside the world of sport itself.

Nevertheless, strong pressures from international sport governing bodies convinced the football establishments of the three ethno-national groups to finally merge into a unified Bosnian Football Federation (NFSBiH) in 2002 and to organize the first united Bosnian post-war championship, named the Premijer Liga. This paper examines the consequences of such a revamped inter-ethnic competition both in terms of the reintegration of the Bosnian population, on the one hand, and the possible exacerbation of ethnic tensions, on the other.

Several studies have analysed the role of sport in promoting social integration and development, ${ }^{4}$ particularly in conflicting societies, ${ }^{5}$ highlighting both the alter-globalist ${ }^{6}$ and neo-colonialist ${ }^{7}$ potential of sport as a civilizing medium. Many scholars have warned about the difficulties in assessing sport's impact on social regeneration, ${ }^{8}$ which are also due to the complexity of the field and the variety of actors involved. ${ }^{9}$ As noted by Gasser and Levinsen while analysing the Open Fun Football Schools programme in BiH, the achievements of sport-based interventions depend heavily 'on the interactions between local, national and international players as they struggle to advance their multiple agendas in both the little game (football) and the big one (winning the peace)'. Hence, 'OFFS longterm success hinges on the successes of the local officials, international organizations, international and national sporting bodies and others who work to develop Bosnia and Herzegovina as a multi-ethnic nation'. ${ }^{10}$ The impact of 'bottom-up' sport initiatives at the ground level in polarized communities strictly depends on the consequences of 'top-down' interventions and governance dynamics on the overall context. While the former are often intentionally designed to generate social integration, the latter affect peace-building processes also through the indirect fallout of their own functional and organizational 
logics. This is the case, for example, of the partial discrepancy between the criteria adopted by FIFA, UEFA and the IOC to accept new member federations, on the one hand, and those embraced by the UN to recognize state sovereignties, on the other. By examining the reunification of Bosnian football after the bloody wars of the 1990s, the paper seeks to explore this multi-layered interplay.

Since an exclusive focus on ethnicity would run the risk of reifying ethnic-based representations, the role of Bosnian football will be analysed in relation to the broader interaction order and power system which such representations serve to hide and/or legitimize. Indeed, a key issue in $\mathrm{BiH}$ is the way social distrust is nourished and ethnicized by the ruling elites. According to Bieber, 'ethnic distrust is both a way to channel broader frustration and a mechanism to re-produce distrust'. Such a mechanism causes 'disengagement from politics and helps to sustain parties that re-affirm low trust politics and, while not being particularly trusted themselves, direct high levels of distrust elsewhere'. ${ }^{11}$

The paper draws on ethnographic research conducted in BiH since 2003 through participant observation, in-depth interviews and informal conversations, complemented with the study of other secondary data, notably content analysis of various media sources. The fieldwork was carried out with a primary focus on football practitioners (players, coaches, officials, supporters) from semi-professional to grass-roots level, while simultaneously sharing everyday interaction with various kinds of other ordinary people. ${ }^{12}$ The secondary data were collected both directly in the field and by monitoring a wide range of online sources, thus ensuring a broad and differentiated access to information, in order to partly offset the bias of the involved and situated perspective. ${ }^{13}$

Moving from Gasser and Levinsen's remark that 'as a terrain for re-integrating communities polarized by war, football is something like frontline farmland: fertile, but likely to be mined, ${ }^{14}$ the paper is divided into three main parts. The first part illustrates the condition of football in the post-war Bosnian context by analysing the interplay between ethnicity, socio-economic inequalities and power relations. The second part explores the connections between the growing unification of the Bosnian football community, the qualitative development of Bosnian football and the potential overcoming of the particularistic system hidden behind ethnic division. The third part analyses the enduring capacity of the criminal elites who lead Bosnian football to preserve the status quo, thus demonstrating how the first decade of a partly unified Bosnian championship - besides providing opportunities to downplay the relevance of ethnicity - has also generated a 'mined field' where ethno-national tensions continue to be fostered. 


\section{Ethno-nationalist profiteers: the exploitation of Bosnian football}

In contrast to what happened to other ex-Communist countries, the Yugoslavian breakdown took place through armed conflict. Ethno-nationalist politics guided by Milošević and Tudjman led to the war between Croats and Serbs, which quickly spread to the territory of $\mathrm{BiH}$, involving its multiethnic population.

The tremendous conflicts of 1992-1995 accelerated the ethnic polarization in $\mathrm{BiH}$, thus forcing the people to side with one or the other ethnic group. ${ }^{15}$ The country's social landscape drastically changed after 97,207 people died or disappeared $(2.2 \%$ of the population $)^{16}$ and half the population of 4.4 million was displaced (1.2million emigrated outside the boundaries of the state and another million left their places of origin remaining within $\mathrm{BiH}){ }^{17}$

While stopping the fighting, the US-brokered Dayton Peace Agreement of November1995 froze and legitimized the situation generated by the war after more than three years of violence, atrocities and ethnic cleansing. The formal integrity of the state was preserved by making ethnic differences integral to the new Bosnian institutional design. ${ }^{18} \mathrm{BiH}$ was established as a single country with two separated entities: the Republika Srpska (RS) and the Federacija ${ }^{19} \mathrm{BiH}$, the latter comprising Croats and Bosniaks, who were themselves actually divided at the cantonal level.

A complex administrative system guaranteed equal representation to the three Bosnian 'constitutive peoples' by trebling every political seat, thus creating hypertrophic, but weak and inefficient central institutions, while leaving great autonomy and power at the local level (entities, cantons, municipalities). This was partially balanced by establishing the UN Office for the High Representative, endowed with the so-called Bonn powers to impose a wide range of decision over the local politicians and even to dismiss some of them, thus making $\mathrm{BiH}$ a semi-protectorate. ${ }^{20}$

Reflecting the country's general situation, the condition of post-war Bosnian football was disastrous: inept speculators with no passion for sport capitalized on the ethnic rhetoric to rule three distinct federations, exploiting the few available resources and causing further impoverishment of the game's quality. As each ethno-national group began to organize its own competition separately, post-war football was played into mono-ethnic areas.

Nevertheless, following strong pressures from FIFA, UEFA and the IOC, the football establishments of the three ethno-national groups finally consented to come together into a unified Bosnian Football Federation ${ }^{21}$ in 2002. The new Federation was shaped following the Dayton model, with a tripartite presidency and a seats-rotation 
system between the representatives of each ethno-national sub-federation, which continued to exist separately. Although intended to be a temporary solution, this structure operated until April 2011, when the UEFA suspended the NFSBiH and replaced its board with a 'normalization committee' in charge of mediating between the Federation's members, and finally amended the statute by replacing the current tripartite-rotational structure with a single-member presidency (the consequences of this change will be discussed later in this paper).

The first united Bosnian post-war championship named Premijer Liga was organized in 2002, while the lower divisions remained ethnically separated at the entity and regional/cantonal levels (with the Prva Liga Federacije $\mathrm{BiH}$ and the Prva Liga RS henceforth serving as the second national leagues). A united championship was also organized at the youth level since the 2003-2004 season, but only for the country's U-18 best teams, while all the other youth tournaments remained separated. When the Premijer Liga started, just seven years after the end of the armed conflict, there were many concerns about its possible negative consequences in terms of inter-ethnic tensions. Actually, by putting teams and fans from different ethnic backgrounds into contact, the football world became a potential 'mined field', giving room both to physical and (mainly) verbal/symbolical/psychological violence. Nonetheless, a deeper understanding of the role played by ethnicity in shaping the Bosnian context during and after the war helps to highlight also the integrative potential of a unified Bosnian football world.

\section{Ethnicity, particularism, clientelism}

Following the Yugoslavian breakdown, ethnicity and nationalism became the main basis to gain political legitimacy and economic power in BiH. The ethno-nationalist ideology, characterized by the claim to establish new nation-states based on ethnic dominance or homogeneity, was rhetorically used to hide and reshape the symbiotic relationship between political power and organized crime structures. ${ }^{22}$ Inter-ethnic trust was broken by creating separated (mono-ethnic) life-worlds, thus fuelling tensions and feeding the war through the propagandistic demonization of the 'others'. Such a separation has been maintained and reinforced in post-war everyday life, within each of the three life-worlds, by strengthening the symbolic representations of distinctive imagined communities through the antagonist reconstruction of physical symbols (notably religious buildings and cultural monuments) ${ }^{23}$ and the differentiation of flags, school textbooks and programs, streets names and signs, tourist guides, etc. In this way, the newly reshaped physical, cognitive and emotional landscapes have been further embodied into visibly displayed banal nationalism, thus rewriting Bosnians' history culture. ${ }^{24}$ Ethnic hatred, hostility and intolerance therefore 
have to be considered both as a tool used by the local political and criminal entrepreneurs to feed the war, and as a result of the war itself, rather than simply the cause of the conflict. $^{25}$

In the post-war $\mathrm{BiH}$, local elites were often composed of people who had gained power positions through illegality and crimes during the conflict while championing the ethnic cause. Victorious nationalists continued the Balkan tradition of patronage ${ }^{26}$ by replacing the communist ideology with the ethno-national one. Ethnicity became the recognition criteria used by the local elites to legitimize particularistic allocations and parasitic use of social power. Furthermore, it was (and continues to be) used to deny responsibilities by laying the blame on the other groups. As the allocation of resources is mainly based on cronyism and ethnic affiliation rather than redistributive justice and professional qualifications, in each field of Bosnian society, many competent people have been relegated to the lowest ranks of the social hierarchy. ${ }^{27}$

Those people who reject the exclusive hegemony of the ethnic self-representation in favour of more universalistic and meritocratic criteria of recognition can be considered as a liminal group composed of individuals who share a marginal position within the power structure $^{28}$ and would therefore have an interest in acting collectively to improve their condition. Nonetheless, they tend to remain a quasi-group until they do not find the conditions for their aggregation and mobilization ${ }^{29}$ alongside different cleavages, alternative to those defined by the ethno-national belongings.

Meanwhile, at the top of the social pyramid, the nationalist elites of the three groups stage the ethnic struggle in front of public opinion, only to then partake in the advantages of such an 'ethnic sharing' of power and exploited resources, when they are backstage. ${ }^{30}$ Being tacitly allied and mutually concerned with maintaining the relevance of the ethnonational cleavage, they prevent a large part of the population - disadvantaged by this socio-political order - from coalescing against them alongside the ethnically cross-cutting socio-economical cleavages. ${ }^{31}$

\section{Inverting the route?}

Such a vicious circle is also evident in Bosnian football, exploited by incompetent (and sometimes criminal) elites who do not care about the decreasing standards of the game. Especially in the first post-war years, the leaders at the NFSBiH utilized the national team to pocket money from useless friendly matches, as well as to cap unknown low-quality players, thus increasing their value and selling them internationally through their agents ( $\mathrm{BiH}$ has a higher proportion of FIFA players' agents for its footballers than any other country). ${ }^{32}$ Local championships have also been habitually exploited through match fixing, 
clientelism and illegal misappropriation of Federation's funds. Similar attitudes characterize the practices of many club officials who manage public resources for private enrichment without making any personal investment, as football clubs in $\mathrm{BiH}$ are not private companies, rather public associations predominantly funded out of municipal budgets. This situation reduces the spectators' interest and the public relevance and visibility of Bosnian football, thus removing it from the public view and favouring its privatistic and parasitic management by the incompetent elites, while further disempowering the competent operators and football enthusiasts.

Therefore, the unification of Bosnian football can be considered to be a 'fertile land' mainly if (and insomuch) it helps to break such a vicious circle, i.e. to (1) settle the ethnonational separations by enabling a wider imagined community, (2) re-publicize football by restoring its visibility and accountability and (3) enhance the quality of football by promoting meritocracy. This virtuous circle would foster a 'displacement of conflicts', downplaying the relevance of the ethno-national cleavage (Bosniaks vs. Croats vs. Serbs) while highlighting the meritocratic confrontation (competent/enthusiasts vs. criminals/profiteers). It is therefore important to assess if and how the development of a united Bosnian football community provides an arena in which the dominance/relevance of ethnicity as a recognition criteria can be questioned by counter-discourses that celebrate alternative criteria.

\section{Fertile land?}

This section explores the connections between the widening/unification of the Bosnian football community, the qualitative development of Bosnian football and the potential overcoming of the particularistic system hidden behind the ethnic separations.

\section{Settling the ethno-national separations: towards a wider imagined community?}

In football, as in other spheres of Bosnian everyday life, the armed conflict has created three separated worlds, which are still persisting long after the end of the war. This is highlighted by this young Bosnian Serb comments taken in 2004:

\footnotetext{
Do people in RS follow the Bosnian Premijer Liga?

Well ... . we do follow it, yeah, but . . . not as much as we follow or read what happens in Serbia - 'cause the Serbian are our 'brother-people'. I mean, in Republika Srpska you don't have enough information at your disposal to be able to follow what happens in $\mathrm{BiH}$, for instance about football . . . at least if we consider the news that reach us in Republika Srpska. I mean, everybody read Serbian media, everybody eat food made in Serbia, and so on . . . Do you understand what I mean? Although there is also something coming from $\mathrm{BiH}$. . . But we
} 
mainly read the Serbian mass media. You read stuffs coming from Belgrade: Većernji Novosti, Sport, and so on. We read their newspapers, you understand? Otherwise, when I read a Bosnian newspaper . . . we only read about our own teams, those from the Republika Srpska. I may read something about Sarajevo and Želježnićar, but nothing about the other teams . . . (P., 22, from the Bosnian Serb town of Šipovo)

The unification of Bosnian football has contributed to bringing these separated worlds together, at least in part, by stimulating the football enthusiasts to travel to the former 'enemy territory' to attend matches of the newly established Premijer Liga. ${ }^{34}$

Now we have it here very close, in Modrića [Serb town] - I mean, the Premijer Liga - and a lot of people comes from the neighbourhood. A lot of players from Gradaćac [Bosniak town] went to attend the last match, but I've also noticed many people from Šamac, from Ođak [Croat town] . . . Among the neighbouring towns, only Modrića and Orašje have a team in Premijer Liga at the moment, so everybody want to come here to watch Željo, Sarajevo, Čelik, Borac, Leotar ... (S., 37, from the Bosnian Serb town of Modrića)

For many of them, this was their first and only motivation to cross the old front lines and set foot in what was 'enemy territory':

\footnotetext{
Do you travel to Modrića sometimes?

Well, yeah ... Recently we've been there to attend a match of Premijer Liga, and we'll surely go to watch other matches ...

And ... what apart from football? Are you used to go to Modrića also for other reasons?

No, just therefore, just therefore. Well, now I and my friends - those I usually go to the football matches with - have planned to go there also to attend some volleyball match, when the championship will begin. You know, Modrića is close to Gradaćac, it's not far. (I., 34, from the Bosniak town of Gradaćac)
}

The unification of Bosnian football has increased the occasions for encounters, especially among people who already knew each other before the war, but had been separated by the conflict. ${ }^{35}$ This is particularly the case for many people who are actively involved in football as trainers and athletes, especially at grass-roots level. Eager to get out of a selfreferential mono-ethnic football world that limits the possibilities for constructive confrontation, which is necessary to sporting improvement, many sport enthusiasts welcome the enlargement of the Bosnian football landscape as an occasion for comparison and reflexivity. For instance, just after getting to know a Bosniak colleague from a neighbouring town, a Bosnian Serb youth coach told me: 
I've just got to know Alija. He has immediately invited me to play some friendly match in their town, and I don't back down, this is what I want to do with the children that I'm coaching. I'm in favour of such initiatives, because . . . I want to support the club I work for, and create a good football school. Therefore . . . I take this upon myself, so that I can see which teams from Federacija BiH have more money, and which of them are working better with the children. There, the first goal at the moment is to reach them, see where we are positioned when compared to them, try to play with them. It's neither that easy, nor that quick, but . . . this is our first goal . . . So far, we have achieved very good results with our youth teams in Republika Srpska playing against the youth teams of Leotar, Slavija, Glasinac, Sokolac, which are all clubs from Premijer Liga or Prva Liga. But we don't know where we are positioned, when compared to the teams from the Federacija . . . (R., 43, youth coach from the Bosnian Serb town of Nevesinje)

Another important element contributing to the widening of the Bosnian imagined community is the increasing mobility of players, especially at the professional level. While teams used to be mono-ethnic when the Premijer Liga began in 2002, they are now increasingly becoming mixed. Similar to other professional activities, football enables the development of weak ties among people who downplay ethnicity while focusing on the pursuit of common achievements/interests. ${ }^{36}$ At the same time, such a process enhances the relevance of the team's sporting identity while reducing, at least in part, its ethnic representativeness ${ }^{37}$ :

At the very beginning of the new Premijer Liga the teams were mainly mono-ethnic, but now, say, a Muslim guards the goal of Borac [the team of Banja Luka, the main Bosnian Serb town], a Serb is the main striker of Željo ['Bosniak' team from Sarajevo], a Muslim goes to play for Zrinjski [the 'Croat' team of Mostar], the coaches . . . the coaches go and interchange, the players interchange as well ... I think that it [the Premijer Liga] has had quite a good influence on this exchange between people. (E., 42, youth coach from the Bosniak town of Bosanska Krupa)

Further steps towards the normalization of Bosnian football can be noticed from the progressive shift from ethnic rivalries to traditional local and sport rivalries. Classic matches between famous teams catalyse more interest than others, no matter what the ethnic backgrounds of the teams are. For instance, the match between the Bosniak team Želježnićar and their Bosniak city rivals Sarajevo is much more thrilling than the match between Želježnićar and the Croat team Orašje, or the Serb team Leotar.

Also, the classical rural/urban cleavage ${ }^{38}$ often becomes more relevant than the ethno-national one in the unified Bosnian football arena. For instance, when the Croat 
team of Široki Brijeg from Herzegovina complained about being damaged by the NFSBiH in favour of the biggest teams Želježnićar and Zrinski in 2004, they did not relate the discrimination to ethnic reasons - Zrinski is a Croat team as well, indeed - rather to the fact that Široki Brijeg was penalized for being a small peripheral town while Želježnićar and Zrinski benefited from representing themain cities of Sarajevo and Mostar, respectively. ${ }^{39}$ Common urban roots and belonging can become more relevant than ethnonational affiliations, as indicated by the director of Slavija, the club of the Bosnian Serb part of Sarajevo:

Let me tell you this: even nowadays our football team Slavija has far better relationships with Željo and Sarajevo than with Borac of Banja Luka! Now, someone might probably ask 'Wait, how is this possible?', but . . . it has nothing to do with the usual ethnic antipathy, it is not the reason why we are in good terms with someone rather than others, in this case. We are in better terms with someone simply because ... sport circumstances require that we are in better terms with them rather than with Borac. And when we come to Modrića . . . we couldn't stand each other's sights, we couldn't even look in each other's eyes . . .

Before the war or after it?

Before the war they didn't even exist! We were like Bundesliga to them! They were really kind of a peasant-team ...

\section{Re-publicizing football by restoring its visibility and accountability}

Another crucial issue to be examined is whether the unification of the Bosnian championships, by promoting a wider imagined community out of the three separated mono-ethnic worlds, can contribute to re-publicization of football as a public good, rescuing it from the hands of the current incompetent elites.

The connection between the visibility and accountability of football can be explored by analysing the perceptions of the Bosnian enthusiasts about the quality of refereeing after the first two seasons of the new Premijer Liga:

Well . . since they have made a unified Premijer Liga the level is increasing. The fact that referees come from different areas has enhanced the quality of refereeing. Quite a selection has been made, preventing some people from refereeing, whom I don't know how had been included in those lists: there were some refs here . . people who were outside the world of sport before the war, but then the war - I don't know how - has helped to fly very high. However, the way they flew high, the same way they've fallen down! In short, the level has improved. I follow the Premijer Liga, as far as I can, in Tuzla, now in Modrića, sometimes I go to Sarajevo, and I can tell that the level of refereeing is much better than it was just after the war. (N., 37, youth coach from the Bosniak town of Gradaćac) 
These narratives, collected in 2004, tend to connect football accountability to the increase of both its national and (potentially) international visibility:

I think that now the situation with the referees has improved, but only at the level of Premijer Liga, the unified one, because now those refs aspire to referee in the European Cups - they can't referee in the Champions League yet, we haven't that level yet, but they could referee for instance in the UEFA Cup. Yeah, I think that now the refereeing has a bit improved there, but in the lower categories I think that things are not going well yet . . (D., 39, from the Bosnian Serb town of Modrića)

The difference between the Premijer Liga and lower leagues seems to further confirm the impact of the new enlarged tournament in connecting football visibility and accountability:

Now I tell you how it works here. It doesn't matter if you're in the first team, or in the youth sector: at home, most of the referees help you, while when you play away . . Ok, now the Premijer Liga is a little changing; but apart from that, if you look at all these lower categories, lower than the Premijer Liga . . . Anyway, in the Premijer Liga they can't referee dishonestly because there are the cameras, you know, one can see it . . . there are controls. (H., 22, from the Bosniak town of Gradaćac)

However, despite these initial signs of change, in the last decade, football has continued to be exploited by criminals and unqualified profiteers. At the same time, the unified football landscape has also provided an arena for the Bosnian enthusiasts' protest and resistance, aiming to restore the public value of football.

Since its first season in 2002, many clubs participating in the Premijer Liga - often led by the country's most historically important clubs Želježnićar, Sarajevo and Borac coalesced across ethnic divides against the Federation's officers, appealing all the other clubs to formally associate in order to better defend their rights, and sometimes even threatening to retire from the tournament. Although contingent clubs' interests were obviously often behind the protests, trans-ethnic collective arguments were used to support the dissent, such as 'the salvation of Bosnian football' and 'cleaning the football house up from corruption'.

Similar arguments were used by the organized fans of the different clubs, who often arranged several trans-ethnic collective protests in front of the NFSBiH seat in Sarajevo, as well as by the BHFanaticos, mainly composed of supporters from the Bosnian diaspora, who usually display their 'Rat savezu!' (War to the Federation!) banners at the national team games. 
Along with the fans, famous players and other public personages are vocal about their opposition to the football establishment. For example, on 30 October 2006, 13 Bosnian national team players (Bajramović, Bartolović, Berberović, Bešlija, Grlić, Grujić, Hasagić, Hrgović, Milenković, Misimović, Papac, Spahić and Tolja) published a letter of protest in the Dnevni Avaz daily after some corruption scandal involving the officials of the NFSBiH in 2004, announcing that they would boycott all national team matches until the Federation's leaders resigned:

\footnotetext{
Regarding all that have happened around our national team, we, football players who currently fight in the pitch for the blazon of the country, feel the need to announce our stances to the public opinion . . . We've had enough that the members of the Presidency Milan Jelić, Iljo Dominković i Sulejman Čolaković, as well as the national team director Ahmet Pašalić, seal the destiny of our football and national team. We will no longer accept call-ups to the national team while these people are performing these functions, hoping that our gesture will mark the first step in the healing of this cancer in our soccer and a new beginning for the national team for which our hearts beat. ${ }^{40}$
}

Nevertheless, not even this sensational stand changed the situation, and the immovable Federation's leaders continued with their unaccountable management, raising further frustration and dissent.

In 2008, the well-known former striker Meho Kodro, who had been appointed as the national team manager in January being guaranteed full independence in the technical management of the side, quickly broke his relationship with the NFSBiH in just a few months after refusing to take charge of the team for a game against Iran in Tehran, arranged by the Federation without his knowledge. On 1 June 2008, while the BiH national side was facing Azerbaijan in a friendly match in Zenica in front of just 50 spectators, a friendly humanitarian game between former Bosnian football legends, organized by Kodro and Elvir Bolić to protest against the NFSBiH, was played in Sarajevo at the same time in front of 15,000 people and broadcasted by the FTV. ${ }^{41}$

In November 2009, the former NFSBiH secretary general Munib Ušanović, together with the finance and marketing secretary Miodrag Kureš, were sentenced to five years in jail over tax evasion and illegal misappropriation of the NFSBiH funds. ${ }^{42}$ However, despite continual scandals, the Federation's officers never resigned and persisted with their criminal management until 1 April 2011, when FIFA and UEFA suspended all Bosnian teams from international competition to punish the unwillingness of the NFSBiH to amend its statute. The tripartite presidency was considered no longer acceptable by the main 
governing bodies of international football, and the Bosnian federation was required to finally have a single president.

Such a measure roused further important statements to support the re-publicization of Bosnian football. Worried that the national team would be prevented from playing the last decisive matches of the Euro 2012 qualification, ${ }^{43}$ the Bosniak member of the $\mathrm{BiH}$ joint presidency Bakir Izetbegović addressed a letter to Joseph Blatter and Michel Platini, the FIFA and UEFA presidents, respectively, appealing for a solution:

Without wishing to interfere . . . in your activities, I voice my sincere conviction that you will find an adequate solution to establish in Bosnia a football organisation of the best quality to allow Bosnia's national team and our clubs to continue taking part in European competition . . . You certainly know that Bosnia-Hercegovina is a complex country . . . It would be unfortunate that irresponsible behaviour of members of our (football) federation prevents our international and local football players from taking part in international matches. Hundreds of thousands of their fans do not deserve that. ${ }^{44}$

Even the Dean of the Sarajevo University wrote a letter to the UEFA President Michel Platini:

Dear Mr. Platini, I've decided to address you on behalf of teachers, associates and more than 40,000 students of the University of Sarajevo, from all over Bosnia and Herzegovina and abroad ... Personally, this is the first time to me to write a letter to any sport organizations. The reason behind my addressing to you is my concern for the football in $\mathrm{B} \& \mathrm{H}$, and thus extending to the B\&H society as well . . Essentially, I want you to recognize the real culprits, no matter from which milieu they come and regardless of their names, and to punish them most severely, and to open a path of healthy development for the football in Bosnia and Herzegovina and without the impact of politics, living in and living from the football, and the same time undermining the system of a country that is allowing them to do so. ${ }^{45}$

The talented midfielder of the Bosnian National team Miralem Pjanić, interviewed by the French newspaper L'Equipe, confirmed:

It's very serious. It's a huge shock for the players and those that love Bosnian football. The people to be blamed are the federation's officials. We are simply hostage to incompetent people, who think only of making profit on the back of our efforts rather than about the team. I hope UEFA and FIFA now take the right decisions. We love our country and we always want to wear its colours. It's not us who should pay. The country is already poor - they cannot take football away from us. Today, lots of people demonstrated outside the hotel where the meeting 
took place. We will discuss it among (the team) but if there is anything that can be done to

help our cause, it must be done. ${ }^{46}$

A temporary solution was found by dismissing the past officials and establishing a normalization committee working under the hugely respected former Yugoslavia coach Ivica Osim, who gained the trust of the ethno-national representatives and worked out a compromise involving a single-member presidency. ${ }^{47}$ This welcome change led to the suspension being overturned on 28 May and the normalization committee, initially set up only to manage the emergency phase, was confirmed as being in charge on 29 October until the end of 2012.

\section{Enhancing the quality of football by promoting meritocracy}

Since the very first seasons of the Premijer Liga, the quest for transparency and accountability in Bosnian football has been linked to the quest for fair competition, meritocracy and improving the playing standards. This connection is well expressed by the words of a Bosniak football enthusiast interviewed in 2003:

In the last round of the championship we went to Modrića, to watch Modrića-Zrinški. But it was an ugly match. You see, while watching that match we recalled the matches that ones we used to play in the late $80 \mathrm{~s}$, and I think those team that played in the then Regional League were much stronger than the ones currently playing in today's Premijer Liga. Nowadays the quality is . . . nothing. Nothing when compared to how it should be, if you look at the English Premijer League, or the Italian championship, or the Spanish one, and so on . . You know, a desire would be that one could see something similar in our country as well. I would like to go to Tuzla, at the Tušanj stadium, to watch Sloboda playing against, say, Željo, or Sarajevo, or whatever, and see just that level, that football. And not to see, on the contrary, a . . . war between two teams! (A., 32, from the Bosniak town of Gradaćac)

Also, the increasing mobility of practitioners and followers slowly generated by the normalization of Bosnian football, by providing occasions for comparison and reflexivity, has contributed to encourage the quest for fair competition, meritocracy and improving playing standards. This link is well exemplified by the words of a Bosniak nonprofessional player interviewed in 2004, just after he signed his first transfer to a neighbouring Serb team in the RS' Second League. The quote shows how, by attending a match of his future team, he had the occasion to compare the standards of football (notably refereeing) in the two Bosnian entities and develop some self-critical reflections, thus eluding the usual ethno-national sanctification of 'us' and demonization of 'them': 
Last time that they (my forthcoming teammates) played away I went to watch the match. The referee really looked like someone coming from a higher category . . . and I was really surprised from the way he refereed. 'Cause both teams were competitive and wanted to win, and the match was balanced. He even disallowed a goal to the home team, a goal that I wouldn't have disallowed. He said he had seen a foul, and that's how he decided . . . The refereeing was excellent, and also the players were fair; if someone got injured, they kicked the ball out to break the game, they apologized ... In our matches it is not like that. Well, I would like that . . if we are better, we win 10:0, and if you are better, you win 10:0. But it's not like that, unfortunately. (E., 31, amateur footballer from the Bosniak town of Gradaćac)

While initially almost all the matches in the BiH Premijer Liga were won by the home teams, such a trend has recently changed and victories of the guest teams are more frequent. ${ }^{48}$ However, the situation has not improved in the lower leagues. Still in 2011, some players of the Prva Liga Federacije BiH publicly asserted that 'Refs are the Bosnian football's greatest evil' and 'Playing under these conditions doesn't make any sense,49; eight teams of the same league jointly protested that 'Time for change has come, 'cause we cannot tolerate such a situation, with Prva Liga FBiH no more being a place for correct people and football enthusiasts'. 50

However, the recent establishment of the normalization committee has fostered the hope for professional competence and passion to finally become the main criteria when appointing people in the leading positions, as exemplified by this quote from a Bosniak youth coach interviewed during the summer of 2011:

It will be much more difficult than people expect. It can't easily happen, now, that some Osim, Hadžibegić, Bajević, who are all worldwide well-known people, suddenly order: 'You will be here, you will be there' . . . I believe in some 3-4 years they will build a good system, so that worthy and competent people, who above of all love football, will float to surface. I myself have had many problems in football because of my stances, and I've been relegated to the margins, so that I've been forced to work with some smaller club, and so on. However, I believe in 3-4 years the right people will reach their deserved place. (E., 42, youth coach from the Bosniak town of Bosanska Krupa)

Nonetheless, many Bosnian enthusiasts remain sceptical about the possibility of eradicating the incompetent elites, as they fear that former officials will use their patronage (clientelar) power to quickly regain charge by manipulating the future elections, after the normalization committee finishes its job. 


\section{Mined field?}

The high conservative capability of the criminal elites who lead Bosnian football by hiding behind ethno-national masks exposes the ambivalent potential of the sporting arena. Besides providing opportunities to downplay the relevance of ethnicity, indeed, the first decade of (partially) unified Bosnian championships has also generated a 'mined field' where the ethno-national tensions can be fostered, giving room both to physical and mainly - verbal/symbolical/psychological violence.

\section{Verbal/symbolic violence}

Since the first Premijer Liga season, slogans and offences have been emphasized through the use of war symbolisms, particularly by the - relatively small, but vociferous - groups of organized supporters. Drawing on derogatory terminology of war, the Serb fans were called 'ćetnik' by the Croat or Bosniak opponents, the Croat fans were called 'ustaša' by the others, while the Bosniaks were called 'balija'. 51

Serb fans occasionally welcomed Bosniak supporters brandishing banners stating 'Nož, žica, Srebrenica' (Knife, barbed wire, Srebrenica), thus celebrating the Srebrenica massacre in which approximately 7000 Bosniaks were killed by Ratko Mladić's paramilitary bands. This obviously offended many Bosniaks; for instance, supporters of Želježnićar from Sarajevo once retaliated by making their own banner stating 'Od Sarajeva do Borika, nigdije neće biti ćetnika!' (From Sarajevo to Borik, there won't be no chetnik), and displaying it to the Bosnian Serb fans of Borac Banja Luka.

Croat banners have been displayed to celebrate 'Ante Gotovina' (a Croat war criminal) and 'Oluja' ('Storm', a huge retaliatory operation against Serbs in 1995). Both Croats and Serbs occasionally use the 'Ubij Turćina' (Kill the Turk) and 'Mrzim Bosno' (I hate Bosnia) banners, while exclusively Serbs use the banners hymning 'Ratko Mladić' and 'Radovan Karadžić'. As far as they are concerned, Bosniak extremist supporters welcome their Croat and Serb opponents by waving Turk flags, thus enforcing the representation of their stadium and the Bosniak-majority area as a hostile Islamized territory.

Nonetheless, a very controversial aspect of the transformations characterizing the unified Bosnian football can be noticed in the trans-ethnic use of ethno-nationalistic offences. Indeed, nationalist symbolisms are sometimes curiously used not to reaffirm one's own ethnic belonging, rather to outrage the opponents as much as possible.

In order to achieve such a goal, some supporters go as far as borrowing symbols and slogans from the other ethnic groups. For example, during the match between two Bosnian Serb teams - Modrića and Slavija - in May 2003, the fans of both teams addressed each 
other with the following offences: 'Stupid chetniks!', 'You love Alija (Izetbegović)', 'Also Radovan Karadžić roots for us!'. In the first case, the term 'chetnik' was used - by Serbs against Serbs - in the same derogatory way in which it is usually used by Bosniaks and Croats against Serbs. In the second case, the opponents were offended by equating them to Bosniaks. In the third case, by claiming to be backed by Karadžić's support, one group's members classified themselves as 'first-class-Serbs' and the opponents as 'second-classSerbs'.

Another example occurred when Široki Brijeg (Croats) played against Želježnićar (Bosniaks) in May 2003. Besides chanting 'Burn the balija!' and 'Kill the Turk!', the supporters of Široki Brijeg also chanted 'Knife, barbed wire, Srebrenica', thus implicitly celebrating the Serbs - who are not exactly supposed to be the Croats' role models! - for the massacre they orchestrated against the Bosniaks. Even more surprisingly, while doing so, they also raised the three-fingers salute, ${ }^{52}$ usually flashed by Serbian soldiers as a nationalist sign during military operations and therefore perceived as highly offensive by the Bosnian Croats themselves.

A third example is even more paradoxical. During the match between two Bosniak teams in August 2003 - Sloboda of Tuzla and Želježnićar from Sarajevo - a banner of the Sloboda's supporters stated 'Why didn't the Serbs kill you as well?'. In this case, it was the Bosniaks supporters who went as far as celebrating the Serbs just to outrage the Bosniak rivals. Despite the severity of such an outrage, it came from people of the same ethnic group and was therefore perceived as a purely sporty offence, instead of an ethnic one.

Insults linked to ethno-national belongings and memories of the recent war have therefore ambivalent consequences. On the one hand, the transformation of the ethnonational outrages into normal provocations between rival fans groups may change their original function and meaning, partially reducing their relevance in terms of ethnic opposition. On the other hand, they provide the Bosnian fans groups more opportunity to provoke one another, making the Bosnian matches more flammable.

\section{Riots and physical violence}

Football riots involving physical aggression have been less common than expected in the unified Premijer Liga, although a number of serious incidents did occur during these 10 years. One of the main reasons for the relatively low intensity of fights is the small number of fans attending the Bosnian championship, with core groups of organized supporters usually numbering just dozens or, at most, hundreds of people. ${ }^{53}$ Furthermore, a strong police presence has helped to reduce riots (according to some of my interviewees, there are 
sometimes more policemen than fans in the stadium). On the other hand, especially in the first Premijer Liga seasons, the police have been criticized for unfair treatment of visiting supporters, thereby contributing to make the stadium a hostile territory for the guest teams and their followers.

Although thousands of matches have proceeded quite peacefully in the Premijer Liga since its beginning in 2002, the relatively few incidents ending up in physical confrontation and damage immediately attract the attention of the mass media. One of the most discussed cases was the death of Vedran Puljić, a Sarajevo fan killed before a match in Široki Brijeg in 2009. More recently, much attention was also paid to three important incidents that happened within a couple of weeks between September and October 2011: the fans of Borac attacking those of Želježnićar in Banja Luka, the supporters of Zrinski assaulting the players of Velež during the derby in Mostar and the (supposed) fans of Hajduk Split fighting followers of Želježnićar before a friendly match in Sarajevo.

The increased frequency of the riots appeared to reflect a rise in inter-ethnic intolerance, thus recalling the Yugoslavian football clashes which preceded the war in the early 1990s. ${ }^{54}$ Yet, many observers highlighted that the incidents happened - in close succession and in all the three main ethno-national cities (Banja Luka, Sarajevo and Mostar) - in the very week when a delegation of UEFA and FIFA was awaited in Sarajevo to discuss the possible extension of the normalization committee's mandate. ${ }^{55}$ The incidents might therefore have been devised and orchestrated by former members of the football establishment who had been dismissed and marginalized after the settlement of the normalization committee. According to this interpretation, they aimed at undermining the positive atmosphere of inter-ethnic cooperation already established by the committee in just a few months, thereby 'proving' its ineffectiveness and leading to its removal. ${ }^{56}$

\section{Media amplification}

The impact of all these forms of physical and verbal/symbolic violence on the Bosnian public opinion depends very much on the way they reverberate through the usually factious media coverage. Indeed, despite several heroic stories of extremely qualified editors and journalists who paid high personal prices for impartially reporting about the social and political events before, during and after the Yugoslavian breakdown, the majority of the mass media are presently controlled by the ruling ethno-nationalist elites. ${ }^{57}$

Bosnian media coverage of football riots contributes to intensify ethnic separation in three main ways, i.e. through out-groups denigration, inter-ethnic fights amplification and out-groups misrecognition. 
The first and most common way consists highlighting and stigmatizing the outrages perpetrated by the out-group fans, while downplaying those committed by in-group supporters. For example, after the riots between the Šroki Brijeg fans (the Škripari) and those of Sarajevo (the Horde Zla), Bosniak media celebrated the killed Sarajevian fan Vedran Puljić as a victim of the Croat hooligans, while Croatian media portrayed the alleged murderer Oliver Knenzović as the defender of the city from the predetermined attack launched by Horde Zla.

The second way consists the very amplification of inter-ethnic fights between football fans, which, even when non-factiously accounted, plays into the hands of those arguing for the impossibility of inter-ethnic peaceful cohabitation. As bad football stories are generally considered more newsworthy than good ones, football stadia are more frequently depicted as 'mined fields' rather than fertile lands. It follows that mass media, by simply reporting about football riots, serve as a megaphone for messages and gestures spreading nationalistic hatred, even independently from any politically driven editorial line. $^{58}$

A third contribution to enforce the ethno-national partition is made by the majority of the Croat and Serb media through their agenda setting, which pays more attention to the sport news regarding athletes and teams from Croatia and Serbia, while only marginally reporting $\mathrm{BiH}$ sport by presenting it together with (or even after) international sport news. Such an approach is more evident in the Serb media, which take advantage of RS being a formal administrative entity with high territorial autonomy to ambiguously present the sporting news about $\mathrm{BiH}$ as if they regard it as a foreign country.

The impact of mass media on inter-ethnic relations and power networks can thus vary from extremely direct and explicit to more indirect and unintentional forms. As an example of the first pole, mediated statements about sport can be used by the ethnonational leaders to increase social distrust, as the RS President Milorad Dodik did by publicly declaring that he supports the Serbian football team and would only cheer for $\mathrm{BiH}$ if they were playing Turkey, or that the RS will accept to further stay within BiH only if, among other things, it will be allowed to have its own sport representative team at international competitions. ${ }^{59}$ On the other hand, given the link between ethnicity and patronage networks in the Bosnian power system, by simply highlighting football riots, mass media contribute to nourish the social distrust which feeds patronage relations and corruption dynamics in Bosnian football and society at large. ${ }^{60}$ 


\section{Conclusion}

This paper has sought to illustrate the complex role played by the reunification of the Bosnian football landscape in affecting socio-political identities and power relations in the post-war environment. On the one hand, football reunification has surely contributed to further unveil how ethnicity is instrumentally used by the Bosnian elites to exploit the common good for their private enrichment. To use Hirschmann's words, ${ }^{61}$ in a country where people are mainly divided between the loyalty option (i.e. accepting and actively supporting ethno-national politics) and the exit one (i.e. passively giving up after experiencing frustration and resignation), the football world becomes, at least in part, an arena where those who are disempowered by the current status quo can express their voice. At the same time, while confirming football's potential for the mobilization of public opinion, the Bosnian case shows how it can also be easily used by the establishment to preserve the status quo.

A distinction can be made between the public sphere, built upon ordinary interactions among football practitioners and enthusiasts, which provides fragments of normalization and de-ethnicization of the everyday life, and the far more visible media space which spreads to a broader audience mainly negative news about incidents and fights, rather than positive reports regarding spectacular matches, local football stars or the festive atmosphere in crowded stadia.

Hence the quest for fair competition, meritocracy and improved playing standards, implicit in the inner logics and rhetoric of sport, and supported by many Bosnians keen on football, had only limited success in advocating transparency and accountability. To a large extent, the football world has mirrored the country's social and political evolution, going from a partial normalization of inter-ethnic relations in the early 2000 s to an increasing impasse in the later years, nourished and capitalized on by the ruling parties. The partial autonomy of football from other social spheres, based on both its inner logics and its reliance on international independent governing bodies, still seems too weak in $\mathrm{BiH}$ to challenge the hegemony of the political and criminal elites. The constitution of a professional clubs association in charge of directly running the championships (so far managed by the NFSBiH), together with the transformation of football clubs from public (municipal) associations into private companies, would plausibly increase officials' accountability and motivate them to assume their own responsibilities.

Nonetheless, whereas changes 'from below' find it hard to emerge, the partial autonomy of sport displays its effects 'from above' through decisions imposed by FIFA and UEFA. Breaking away from the Dayton model, the new NFSBiH is becoming the first Bosnian institution to be headed by a single president, i.e. without the rotational balance 
system which is usually claimed to guarantee each 'constituent people' not to be overpowered by the others. However, this very system has so far paralysed $\mathrm{BiH}$, since the fear of becoming a minority was used - sometimes with good reason, sometimes speciously - to impose vetoes on any kind of political, social and economic reform. Hence, the new Federation could serve as a testing ground for possible transformations of the broader institutional apparatus, providing insightful answers to some crucial questions: What will happen to the Croats and Serbs in Bosnian football henceforth? Will things work better - both generally and for them - or will they be overcome by the Bosniaks? Moreover, in the event that it works better, will this experience constitute an example also suitable for the BiH politics, or will it simply be attributed to the peculiarity of the sport world?

Although this last question recalls once again the unsettled scientific challenge of isolating sport's impact from the many other societal influences (politics, media, economy, judiciary and police will certainly play a great role either in supporting or boycotting the work of the normalization committee), the Bosnian context surely represents an insightful case for further research and observation.

\section{Acknowledgements}

Part of the research for this paper was funded by the University of Padua, Italy, through a PhD grant and a subsequent senior research grant. The author is also indebted to Alan Bairner and Oliver S. Williams for their precious support and valuable remarks.

\section{Notes}

1. Bradley, 'In-Groups, Out-Groups'.

2. Bairner and Shirlow, 'Territory, Politics and Soccer Fandom'.

3. Numerato, 'Between Small Everyday Practices'.

4. For some example, see Beutler, 'Sport Serving Development and Peace'; Jarvie, 'Sport, Development and Aid'; Kay, 'Developing through Sport'; Spaaij, 'Social Impact of Sport'; Vermeulen and Verweel, 'Participation in Sport'.

5. Sugden and Bairner, Sport in Divided Societies; Gasser and Levinsen, 'Breaking Post-War Ice'; Rookwood, Social Development in Post-Conflict Communities; Schulenkorf, 'Sport Events and Ethnic Reconciliation'; Armstrong, 'Lords of Misrule'; and Sorek, Arab Soccer in a Jewish State.

6. Kidd, 'A New Social Movement'.

7. Darnell, 'Power, Politics and Sport'. See also Giulianotti, 'Human Rights, Globalization and Sentimental Education'.

8. Coalter, 'Sports Clubs, Social Capital'.

9. Giulianotti, 'Sport, Peacemaking and Conflict Resolution'.

10. Gasser and Levinsen, 'Breaking Post-War Ice', 471.

11. Bieber, 'Negotiating Division and Co-operation'. 
12. Most of the fieldwork was realized in Gradaćac, a Bosniak town in the Tuzla canton, very close to the Republika Srpska (the Bosnian Serb majority entity) and the Posavina canton (with Bosnian Croat majority). I spent eight continuative months with a Bosniak family in 2003, training with the local football team Zvijezda (which was playing in the semi-professional third Bosnian league at that time) and broadly sharing the ordinary people's everyday life. The fieldwork was continued through further periods of several weeks between 2004 and 2006, and is currently being followed up in 2011-2012. The bias of such an in-depth involvement with a Bosniak majority community was partly balanced both by frequently visiting the neighbouring towns with Croat and Serb majority, chiefly Modrića, and by attending the seminars and activities of the Open Fun Football Schools humanitarian project, which provided numerous opportunities to visit non-Bosniak areas while observing, interviewing and playing with many Bosnian Croat and Serb football practitioners and enthusiasts.

13. The in-depth knowledge accumulated during the fieldwork proved to be a crucial asset to filter the monitored news by better recognizing the degree and quality of their bias, and consequently their author's social, ethnic and political orientation. A wide range of sources was consulted, from highly factious to independent ones, based in all the three ethno-national areas.

14. Gasser and Levinsen, 'Breaking Post-War Ice', 471.

15. Oberschall, 'Manipulation of Ethnicity'.

16. The dead and missing are $66 \%$ Bosniaks, $26 \%$ Serbs and $8 \%$ Croats. $41 \%$ of the dead and missing are civilians, $83 \%$ of whom are Bosniaks (Belloni and Hemmer, 'Bosnia-Herzegovina', 131).

17. Sekulić, 'Forced Migration and Perception', 84.

18. Belloni, State Building and International Intervention, 3. See also Campbell, National Deconstruction.

19. Following the Bosnian grammatical rules, the term will change throughout the text being spelled either Federacija or Federacije according to its accusative or genitive form.

20. Bieber, Post-War Bosnia.

21. Namely, Nogometni/Fudbalski Savez Bosna i Hercegovina, including both the 'Croat' and 'Serb' words for football ('nogomet' and 'fudbal', respectively) in order to avoid disputes.

22. Far from being a Bosnian (or Balkan) peculiarity, this evolution of the political/criminal relationship simply highlights how 'the global neo-liberal economy de-structures traditional organizational models, empowers intermediation, and gives organized crime a formidable opportunity to emancipate itself from the traditional role of provider, often allowing direct intervention in the management of political violence and in the moulding of state structures' (Strazzari, 'Decade Horribilis', 185).

23. See Hayden, 'Antagonistic Tolerance'.

24. For a detailed description, see Torsti, 'History Culture'. For the concept of banal nationalism i.e. the ways in which a nation is symbolically 'flagged' in the habitual, everyday life practices of ordinary people - see Billig, Banal Nationalism. 
25. This interpretation does not deny the existence of ethnic differences and tensions (see, for instance, Hayden, 'Antagonistic Tolerance'), but highlights how they are emphasized and instrumentally used in the Bosnian context as a pretext and cloak for a clientelist patronage system. See Bose, Bosnia after Dayton; Burg and Shoup, War in Bosnia-Herzegovina; Chandler, Bosnia: Faking Democracy; Pickering, 'Generating Social Capital'; and Sekulić, Massey, and Hodson, 'Ethnic Intolerance and Ethnic Conflict'.

26. See Woodward, 'Bosnia after Dayton'.

27. Discriminatory hiring and firing was accelerated during the war and immediately following it (OSCE, Employment Discrimination), but clientelism and patronage keep on dominating Bosnians' life nowadays.

28. See Turner, Ritual Process.

29. See Dahrendorf, Class and Class Conflict.

30. Such a power system is based on the disenchantment of the most competent, educated and cosmopolitan part of the Bosnian population, which contributes to push the electoral abstention up to $50 \%$. It is mainly the rural population that votes, which is more easily manipulated by the ethnonationalist through politics of fear, as 'fear of how the other sides will vote drives voters to choose the party of security for their own ethnicity’ (Belloni and Hemmer, 'Bosnia- Herzegovina', 133). 31. Although often hidden by the dominant ethno-national representation, many other social cleavages are displayed in the Bosnian context, cross-cutting the barriers of ethnic identity. They regard prevalently the problems not only of distribution of restricted material resources, but also of differences related to attitudes, mentality, customs, culture in general and political choice. The fluxes of refugees and internal displaced persons further increases this inter-, intra- and trans-ethnic complexity (Sekulić, 'Forced Migration and Perception', 92).

32. There are 123 FIFA licensed players' agents in BiH, more than in the Netherlands, Portugal, Russia or Turkey, for instance. Only Italy, Spain, UK, Germany, Brazil, France and Argentina have more agents and also far more players than BiH (see Dautbegović, 'BiH osma u svijetu'; see also http://www.fifa.com/aboutfifa/organisation/footballgovernance/playeragents/list.html).

33. Schattschneider, Semisovereign People.

34. As shown by other researches in different polarized communities, fear often prevents people to cross old front lines despite an ongoing peace process (see, for instance, Bairner and Shirlow, 'When Leisure Turns to Fear').

35. Recent researches assess that 'by virtue of the nature of pre-war Bosnia-Herzegovina with more mixed communities and histories of relative tolerance, older people ( . . . ) have more friends from different nationalities', although 'younger people show a higher preference for mixed friendships' (O’Loughlin, 'Inter-Ethnic Friendships', 48).

36. See Pickering, 'Generating Social Capital'.

37. This would be in line with the broader tendency of contemporary sport to contribute to deethnicize nations and to de-territorialize identities (see Poli, 'Denationalization of Sport').

38. About the primacy of the urban-rural factor for questions on current friendship networks, see O’Loughlin, 'Inter-Ethnic Friendships'. 
39. 'Sport', Avaz, May 27, 2003.

40. See http://www.sarajevo-x.com/sport/reprezentativci-bih-nece-igrati-dok-ne-odu-jelicdominkovic-colakovic-i-pasalic/061031019

41. Babić, 'Svi na Koševo'.

42. Zuvela, 'Bosnia Soccer Officials'.

43. As the suspension threatened to damage the then-seemingly-likely qualification of the national team to the European championship in 2012, most of the appeals came from the Bosniaks, who mainly identify with the Bosnian side (while the great majority of the Bosnian Croats and Bosnian Serbs root for Croatia and Serbia, respectively). Nonetheless, pleas also came from the representatives and fans of the Bosnian Serb club Borac from Banja Luka, having just won their first Premijer Liga and therefore expecting to play the UEFA Champions League's preliminaries.

44. See 'Bosnian Leader Appeals to UEFA over Ban'. http://www.kickoff.com/europeanleague/31735/bosnian-leader-appeals-to-uefa-over-ban.php

45. Retrieved from unsa.ba/s/images/stories/pdf/a1-n/uefa.pdf

46. E.T. 'Pjanic: “"Un énorme choc”', L'Equipe.

http://www.lequipe.fr/Football/breves2011/20110329_180655_pjanic-un-enorme-choc.html (accessed March 29, 2011).

47. Wilson, 'Bosnia-Herzegovina's United Return'.

48. Although this does not necessarily mean that match fixing has disappeared - as it rather became more subtle and complex, detaching from the simple rule that 'the home team has to (be made) win' - now results are a little less predictable and therefore the matches are more interesting to the spectators.

49. Škorić, 'Sudije su najveće zlo'.

50. Škorić, 'Osam klubova'.

51. During the WWII, the ćetniks were the Serbian royalist paramilitary combatants, while the ustaša were the soldiers of the Croatian fascist anti-Yugoslav separatist movement. Both names have been recalled during the recent Yugoslav wars in the 1990s and are mutually used as derogatory terms. The word balija, once used to describe descendants of Turks of Ottoman Empire in the Balkans, has become a slang name used for Bosniaks as an insult or description by Croats or Serbs.

52. The three-finger salute is almost exclusively used by Serbs. Apart from having religious meanings, it had also been used as a nationalist sign before and during the Yugoslav wars, and was often flashed by Serbian soldiers during military operations. Therefore, among Serb opponents in the Yugoslav wars - Croats, Bosniaks and Albanians - the three-finger salute is usually perceived as a provocation, especially when directed at them personally.

53. In the first half of the 2010-2011 season, the average attendance in Premijer Liga was 1563 spectator per match (from the 4167 of the Sarajevo team to the 607 of Olimpik). The highest attendance was 15,000 spectators for Sarajevo, 8000 for both Želježnićar and Borac, and 5000 for Celik (http://www.european-football-statistics.co.uk/attn/avebih.htm).

54. Radenović and Karać, 'Sportski tereni'. 
55. Dautbegović, 'Huligani u službi’.

56. Hasić, 'Navijaćki izgredi'.

57. After the decline of the once respected newspaper Oslobodjenje (Liberation) - which managed to maintain a multiethnic staff with high professional standards and impartiality even under the tremendous war conditions, but was not able to 'survive the peace' - independent journalism could be mainly found in the two Sarajevian weekly Dani and Slobodna Bosna, and the newspaper Nezavisne Novine from Banja Luka (whose editor-in-chief Željko Kopanja lost both of his legs in a car-bomb assassination attempt in 1999). For a detailed and touching account of the media's role in the Yugoslavian breakdown, see Kurspahić, Prime Time Crime, partially summarized in Kurspahić, 'Missed Opportunities'.

58. See Skaka, 'BHT1 kao megafon'.

59. Dnevni Avaz, 'Dodik: Spremni smo'.

60. For a deeper reflection on the complex interplay between mass media, sport and corruption - of which the Bosnian case represents an indirect example - see Numerato, 'Media and Sports

Corruption'.

61. Hirschmann, Exit, Voice, and Loyalty.

\section{References}

Armstrong, Gary. 'The Lords of Misrule: Football and the Rights of the Child in Liberia, West Africa'. Sport in Society 7 (2004): 473-502.

Babić, I. 'Svi na Koševo - Spasimo BH. Fudbal' [Everybody to the Koševo stadium - Let's save Bosnian football]. Sportsport.ba. http://sportsport.ba/bh_fudbal/svi-na-kosevo--spasimobh-fudbal/2980

Bairner, Alan, and Peter Shirlow. 'Territory, Politics and Soccer Fandom in Northern Ireland and Sweden'. Football Studies 3 (2000): 5-27.

Bairner, Alan, and Peter Shirlow. 'When Leisure Turns to Fear: Fear, Mobility, and EthnoSectarianism in Belfast'. Leisure Studies 22 (2003): 203-21.

Belloni, Roberto. State Building and International Intervention in Bosnia. London: Routledge, 2008 .

Belloni, Roberto, and Bruce Hemmer. 'Bosnia-Herzegovina: Constructing Civil Society under a Semi-Protectorate'. In Civil Society and Peacebuilding: A Critical Assessment, ed. T. Paffenholz, 129-52. Boulder, CO: Lynne Rienner, 2010.

Beutler, Ingrid. 'Sport Serving Development and Peace: Achieving the Goals of the United Nations through Sport'. Sport in Society 11 (2008): 359-69.

Bieber, Florian. Post-War Bosnia: Ethnic Structure, Inequality and Governance of the Public Sector. London: Palgrave Macmillan, 2006.

Bieber, Florian. 'Negotiating Division and Co-operation in Today's Bosnia'. http://fbieber.wordpress.com/2011/05/31/negotiating-division-and-cooperation-intoday $\% \mathrm{E} 2 \% 80 \% 99$ s-bosnia/ (accessed May 31, 2011).

Billig, Michael. Banal Nationalism. London: Sage, 1995. 
Bose, Sumantra. Bosnia after Dayton: Nationalist Partition and International Intervention. London: Hurst, 2002.

Bradley, Joseph M. 'In-Groups, Out-Groups and Contested Identities in Scottish International Football'. Sport in Society 14 (2011): 818-32.

Burg, Steven L., and Paul S. Shoup. The War in Bosnia-Herzegovina. Armonk, NY: M.E. Sharpe, 1999.

Campbell, David. National Deconstruction: Violence, Identity and Justice in Bosnia. Minneapolis: University of Minnesota Press, 1998.

Chandler, David. Bosnia: Faking Democracy after Dayton. London: Pluto Press, 2000.

Coalter, Fred. 'Sports Clubs, Social Capital and Social Regeneration: "Ill-Defined Interventions with Hard to Follow Outcomes”?’ Sport in Society 10 (2007): 537-59.

Dahrendorf, Ralf. Class and Class Conflict in Industrial Society, 241-8. Stanford, CA: Stanford University Press, 1959.

Darnell, Simon. 'Power, Politics and Sport for Development and Peace: Investigating the Utility of Sport for International Development’. Sociology of Sport Journal 27 (2010): 54-75.

Dautbegović, Mirza. 'BiH osma u svijetu po broju menadžera?' [BiH ranks eighth in the world in number of players managers?]. Sportsport.ba. http://www.sportsport.ba/bh_fudbal/bihosma-u-svijetu-po-broju-menadzera/70396

Dautbegović, Mirza. 'Huligani u službi rušenja Komiteta?' [Hooligans to serve Committee's demolition?]. Sportsport.ba. http://sportsport.ba/bh_fudbal/huligani-u-sluzbi-rusenjakomiteta/65275

Dnevni Avaz. 'Dodik: Spremni smo ostati ako dobijemo svoju reprezentaciju, a od BiH uzmemo što nam treba'. [Dodik: We are ready to stay if we get our national team, and if we can take from $\mathrm{BiH}$ what we need] http://www.dnevniavaz.ba/vijesti/iz-minute-u-minutu/70862milorad-dodik-bih-je-u-fazi-raspadanja-i-niko-joj-ne-moze-pomoci-cak-ni-amerikanci.html (accessed December 16, 2011).

Gasser, Patrick K., and Anders Levinsen. 'Breaking Post-War Ice: Open Fun Football Schools in Bosnia and Herzegovina'. Sport in Society 7 (2004): 457-72.

Giulianotti, Richard. 'Human Rights, Globalization and Sentimental Education: The Case of Sport'. Sport in Society 7 (2004): 355-69.

Giulianotti, Richard. 'Sport, Peacemaking and Conflict Resolution: A Contextual Analysis and Modelling of the Sport, Development and Peace Sector'. Ethnic and Racial Studies 34 (2011): 50-71.

Hasić, Nedim. 'Navijaćki izgredi u Banja Luci i Mostaru izrežirani kako bi se sazvala izvanredna Skupština NS BiH?' [Fans' rows in Banja Luka and Mostar devised in order to have an extraordinary assembly of the NFSBiH convened?]. Slobodna Bosna, September 30, 2011.

Hayden, Robert. 'Antagonistic Tolerance: Competitive Sharing of Religious Sites in South Asia and the Balkans'. Current Anthropology 43 (2002): 205-31.

Hirschmann, Albert O. Exit, Voice, and Loyalty: Responses to Decline in Firms, Organizations, and States. Cambridge, MA: Harvard University Press, 1970. 
Jarvie, Grant. 'Sport, Development and Aid: Can Sport Make a Difference?' Sport in Society 14 (2011): 241-52.

Kay, Tess. 'Developing through Sport: Evidencing Sport Impacts on Young People'. Sport in Society 12 (2009): 1177-91.

Kidd, Bruce. 'A New Social Movement: Sport for Development and Peace'. Sport in Society 11 (2008): 370-80.

Kurspahić, Kemal. Prime Time Crime: Balkan Media in War and Peace. Washington, DC: United States Institute of Peace Press, 2003.

Kurspahić, Kemal. 'Missed Opportunities in Post-War Bosnia'. In Media and Glocal Change: Rethinking Communication for Development, edited by Oscar Hemer and Thomas Tufte, 335-48. Buenos Aires: CLACSO, 2005.

Numerato, Dino. 'The Media and Sports Corruption: An Outline of Sociological Understanding'. International Journal of Sport Communication, 2 (2009): 261-73.

Numerato, Dino. 'Between Small Everyday Practices and Glorious Symbolic Acts: Sport-Based Resistance against the Communist Regime in Czechoslovakia'. Sport in Society 13 (2010): $107-20$.

Oberschall, Anthony. 'The Manipulation of Ethnicity: From Ethnic Cooperation to Violence and War in Yugoslavia'. Ethnic and Racial Studies 23 (2000): 982-1001.

O’Loughlin, John. 'Inter-Ethnic Friendships in Post-War Bosnia-Herzegovina: Socio-demographic and Place Influences'. Ethnicities 10 (2010): 26-53.

OSCE (Organization for Security and Co-operation in Europe). Employment Discrimination in Bosnia and Herzegovina. Sarajevo: OSCE, June 1999.

Pickering, Paula. 'Generating Social Capital for Bridging Ethnic Divisions in the Balkans: Case Studies of Two Bosniak Cities'. Ethnic and Racial Studies 29 (2006): 79-103.

Poli, Raffaele. 'The Denationalization of Sport: De-Ethnicization of the Nation and Identity Deterritorialization'. Sport in Society 10 (2007): 646-61.

Radenović, Vedran, and Goran Karać. 'Sportski tereni ogledalo situacije u BiH' [Sport pitches mirror the situation in $\mathrm{BiH}]$. Nezavisne Novine.

http://www.nezavisne.com/sport/fudbal/Sportski-tereni-ogledalo-situacije-u-BiH108319.html

Rookwood, Joel. Social Development in Post-Conflict Communities: Building Peace through Sport in Africa and the Middle East. Saarbrücken: VDM, 2009.

Schattschneider, Elmer Eric. The Semisovereign People: A Realist's View of Democracy in America. New York: Holt, Rinehart and Winston, 1960.

Schulenkorf, Nico. 'Sport Events and Ethnic Reconciliation: Attempting to Create Social Change in War-Torn Sri Lanka'. International Review for the Sociology of Sport 45 (2010): 273-94.

Sekulić, Duško, Garth Massey, and Randy Hodson. 'Ethnic Intolerance and Ethnic Conflict in the Dissolution of Yugoslavia’. Ethnic and Racial Studies 29 (2006): 797-827. 
Sekulić, Tatjana. 'Forced Migration and Perception of Borders: War-Migrant Associations as a Resource of Integration'. In The Borders of the Polity: Migration and Security across the EU and the Balkans, ed. L. Chiodi, 81-100. Ravenna: Longo Editore, 2005.

Skaka, M. 'BHT1 kao megafon za glas nacionalne mržnje' [BHT1 as a megaphone for the voice of national hatred]. Sportsport.ba. http://sportsport.ba/bh_fudbal/bht1-kao-megafon-za-glasnacionalne-mrznje/63154 (accessed August 25, 2011).

Škorić, E. 'Sudije su najveće zlo bih. fudbala' [Referees are the greatest evil in Bosnian football].

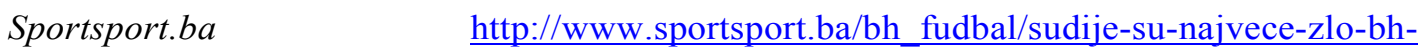
nogometa/67279 (accessed October 31, 2011).

Škorić, E. 'Osam klubova se bori za bolje sutra'. [Eight clubs fight for a better tomorrow] http://www.sportsport.ba/bh_fudbal/osam-klubova-se-bori-za-bolje-sutra/68160

Sportsport.ba (accessed November 14, 2011).

Sorek, Tamir. Arab Soccer in a Jewish State: The Integrative Enclave. Cambridge: Cambridge University Press, 2007.

Spaaij, Ramón. 'The Social Impact of Sport: Diversities, Complexities and Contexts'. Sport in Society 12 (2009): 1109-17.

Strazzari, Francesco. 'The Decade Horribilis: Organized Violence and Organized Crime along the Balkan Peripheries, 1991-2001'. Mediterranean Politics 12 (2007): 185-209.

Sugden, John and Bairner, Alan, eds. Sport in Divided Societies. Aachen: Meyer \& Meyer Sport, 1999.

Torsti, Pilvi. 'History Culture and Banal Nationalism in Post-War Bosnia'. Southeast European Politics 5 (2004): 142-57.

Turner, Victor. The Ritual Process: Structure and Anti-Structure. Chicago, IL: Aldine, 1969.

Vermeulen, Jeroen, and Paul Verweel. 'Participation in Sport: Bonding and Bridging as Identity Work'. Sport in Society 12 (2009): 1206-19.

Wilson, Jonathan. 'Bosnia-Herzegovina's United Return to International Football'. The Guardian. http://www.guardian.co.uk/football/blog/2011/jun/03/bosnia-erzegovina-fifaeuro-2012 (accessed June 3, 2011).

Woodward, Susan L. 'Bosnia after Dayton'. In After the Peace: Resistance and Reconciliation, ed. Robert L. Rothstein, 139-66. Boulder, CO: Lynne Rienner, 1999.

Zuvela, Maja. 'Bosnia Soccer Officials Jailed for 5 Years Over Tax'. Reuters.com. http://uk.reuters.com/article/2009/11/23/bosnia-court-soccer-idUKGEE5AM1E020091123 (accessed November 23, 2009). 